Western North American Naturalist 68(1), (C) 2008, pp. 15-20

\title{
EFFECTS OF WATER TEMPERATURE ON GROWTH OF RAZORBACK SUCKER LARVAE
}

\author{
Kevin R. Bestgen ${ }^{1}$
}

\begin{abstract}
I conducted laboratory experiments and fit a response surface regression model to evaluate growth of endangered razorback sucker (Xyrauchen texanus) up to 37 days post-hatch. Fish growth at ad libitum ration was positively related to water temperature, and larvae reared at $25.5^{\circ} \mathrm{C}$ grew about twice as fast in length and 4 times as fast in weight as those at $16.5^{\circ} \mathrm{C}$. Growth was intermediate at $19.5^{\circ} \mathrm{C}$ and $22.5^{\circ} \mathrm{C}$. Time required for razorback sucker larvae to exceed $25 \mathrm{~mm}$ total length (TL), a potentially important threshold for reduced predation, was 30 days (post-hatch) at $25.5^{\circ} \mathrm{C}, 33$ days at $22.5^{\circ} \mathrm{C}, 36$ days at $19.5^{\circ} \mathrm{C}$, and 41 days at $16.5^{\circ} \mathrm{C}$. Time to exceed $25 \mathrm{~mm}$ TL increased to 52 days under a low growth rate of $0.29 \mathrm{~mm} \cdot \mathrm{d}^{-1}$. Faster growth rates could reduce the time that razorback sucker larvae are vulnerable to predation by abundant and co-occurring small-bodied fish and invertebrate predators in nursery areas. Growth of razorback sucker larvae could be enhanced if flow re-regulation at Flaming Gorge Dam and downstream levee removal restored connections between the Green River and its floodplain and increased availability of warm and productive wetlands.
\end{abstract}

Key words: razorback sucker, temperature, growth, survival, regulated river, predation, wetland, endangered species.

Rivers regulated by dams often exhibit altered flow and temperature regimes and enhanced populations of nonnative fishes, which collectively result in reductions of native kinds (Carlson and Muth 1989, Poff et al. 1997). Prescription of more natural regimes, including increased frequency of high flows that overtop the main channel, may restore portions of the native fish community that use the seasonally inundated floodplain (Stanford et al. 1996, Poff et al. 1997, Muth et al. 2000). Early life stages of endangered razorback sucker (Xyrauchen texanus), an endemic of streams in the highly regulated Colorado River Basin in the American Southwest, use floodplain wetlands in the Green River Basin, Utah, for rearing (Minckley et al. 1991, Modde 1996, Modde et al. 1996, 2001). Survival and recruitment of razorback sucker larvae produced in the mainstem Green River-the only remaining riverine population of razorback sucker that consistently produces substantial numbers of young - may be linked to availability of downstream low-velocity floodplain areas, where relatively warm and food-rich conditions may promote faster growth and higher survival of larvae (Bestgen 1990, Tyus and Karp 1990, Modde 1996, Clarkson and Childs 2000, Modde et al. 2001, Bestgen et al. 2002). Floodplain access is thought to be important because razorback suckers in the Green River spawn during spring high-flow periods in the main channel, where low water temperatures of $12^{\circ}-$ $16^{\circ} \mathrm{C}$ and low food availability may limit growth in the few in-channel low-velocity rearing areas (Tyus and Karp 1989, 1990, Bestgen 1990, Mabey 1993, Muth et al. 2000). Access to high growth environments is sometimes limited because levees restrict river-floodplain communication and spring peak flows are reduced because of storage in Flaming Gorge Reservoir (Muth et al. 2000, Modde et al. 2001).

An additional factor that may limit survival of razorback sucker is sympatric nonnative fishes that prey upon or compete with early life stages of razorback sucker. Over 60 fishes have been introduced into lotic and lentic habitat in the Colorado River Basin, and even macroinvertebrates and small-bodied fishes such as fathead minnow (Pimephales promelas) and red shiner (Cyprinella lutrensis; maximum total length about $75 \mathrm{~mm}$ ), which are abundant in low-velocity nursery areas, are capable of preying upon razorback sucker larvae (Carlson and Muth 1989, Ruppert et al. 1993, Horn et al. 1994, Valdez and Muth 2005, Olden et al. 2006, Markle and Dunsmoor 2007). Fast growth of early life stages of razorback sucker

${ }^{1}$ Larval Fish Laboratory, Department of Fish, Wildlife, and Conservation Biology, Colorado State University, Fort Collins, CO 80523. E-mail: kbestgen @warnercnr.colostate.edu 
could reduce the time larvae are susceptible to size-dependent mortality from abundant predators and may enhance survival and recruitment (Marsh and Langhorst 1988, Rice et al. 1993, Bestgen et al. 1997, 2006, Modde et al. 2001).

Primary factors affecting fish growth are water temperature and the quality and quantity of food (Weatherly and Gill 1987). Growth of razorback sucker larvae fed different diets and rations has been described (Papoulias and Mickley 1990, 1992), temperature preference of juveniles and adults is known (Bulkley and Pimentel 1983), and effects of $10^{\circ}, 14^{\circ}$, and $20^{\circ} \mathrm{C}$ water temperatures on development and growth of early life stages has been investigated (Marsh 1985, Clarkson and Childs 2000). I assessed growth of early life stages of razorback sucker at warmer water temperatures $\left(16.5^{\circ}-25.5^{\circ} \mathrm{C}\right)$ and $a d$ libitum food abundance to simulate growth conditions in Green River floodplain wetlands, where water temperatures exceed $20^{\circ}-25^{\circ} \mathrm{C}$ by late June and where food is abundant (Modde et al. 2001, Christopherson et al. 2004, Modde and Haines 2005). A response surface model quantifies the relationship between water temperature and growth of early life stages of razorback sucker, information which may assist in the recovery of this endangered species.

\section{Methods}

Razorback sucker embryos were obtained in May 1996 from a U.S. Fish and Wildlife Service hatchery in Grand Junction, Colorado. Embryos were transported to Colorado State University, and they hatched 6 or 7 days postfertilization in flow-through Heath trays. Fish were maintained at $18^{\circ} \mathrm{C}$ and reared in fine mesh cages. Newly hatched brine shrimp nauplii (Artemia sp.) were offered ad libitum twice per day beginning 5 days post-hatch, and 1st feeding was noted at 9 days post-hatch. Five healthy 1st-feeding larvae were allocated to each of 12 tanks: 3 tanks were assigned at random to each of the $16.5^{\circ}, 19.5^{\circ}, 22.5^{\circ}$, and $25.5^{\circ} \mathrm{C}$ treatments. Larvae were acclimated over a period of several hours $\left(2\right.$ hours per $1^{\circ} \mathrm{C}$ change from $18^{\circ} \mathrm{C}$ rearing conditions) to treatment temperatures and placed in aerated 2-L flow-through containers. Treatment temperatures generally were chosen to reflect the range of conditions that newly emerged razorback sucker larvae may encounter in Upper Colorado River Basin streams or the floodplain (Muth et al. 2000, Modde et al. 2001). Water temperatures in treatment tanks were monitored several times per day throughout the test period and were maintained within $0.2^{\circ} \mathrm{C}$ of the target; only nominal temperatures were used in analyses.

Total lengths (TL, nearest $0.1 \mathrm{~mm}$ ) of an additional 8 razorback sucker larvae (few fish were available) were measured at 1st feeding (9 days post-hatch) with an ocular micrometer fitted to a dissecting microscope. Their mean length was the benchmark upon which length changes at 23 and 37 days post-hatch (14 and 28 days post-exogenous feeding, respectively) were compared for each treatment. On day 23 post-hatch, all larvae were lightly anaesthetized with MS-222 (25 mg $\left.\cdot \mathrm{L}^{-1}\right)$, measured, and returned to their respective tanks. On day 37 post-hatch, all larvae were sacrificed with an overdose of MS-222, similarly measured, and weighed to the nearest $0.001 \mathrm{~g}$. Growth experiments were discontinued after 28 days post-exogenous feeding because larvae were approaching the size at which small tank size may have limited growth.

Mean total length of razorback sucker larvae in tanks at 9, 23, and 37 days post-hatch $(0,14$, and 28 days, respectively, post-1stfeeding) and mean weight were used as experimental response variables. To avoid potential pseudoreplication, I used tanks as the experimental units rather than individual fish, even though a statistical tank effect was not evident. Mean TL of razorback sucker in each tank (i.e., growth) was compared to water temperature and days post-hatch (including squared and interaction terms) to estimate a response surface function. A quadratic regression model was used to explore different water temperature-growth scenarios over the entire $16.5^{\circ}-$ $25.5^{\circ} \mathrm{C}$ range. All statistical analyses were performed with SAS (Statistical Analysis Systems, version 8.0, SAS, Inc., Cary, NC).

I also solved the response surface equation described above for growth as a function of water temperature and days post-hatch to determine the number of days required for razorback suckers to achieve $25 \mathrm{~mm}$ TL, a size at which razorback sucker larvae may be immune to predation from some small-bodied, gapelimited cyprinid predator fishes (Bestgen et al. 2006, Markle and Dunsmoor 2007). I also 


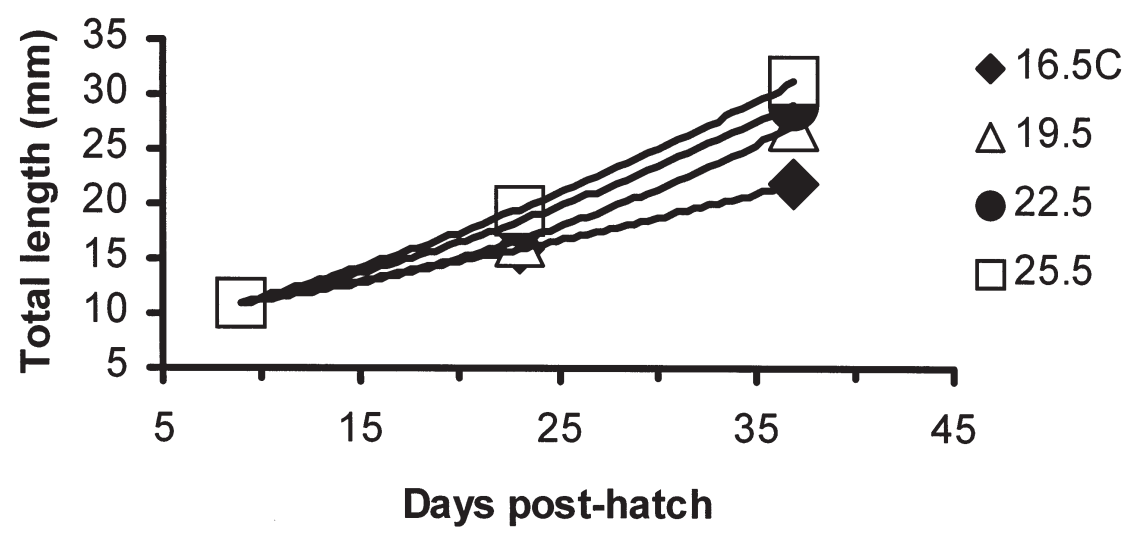

Fig. 1. Growth (change in total length) of razorback sucker larvae as a function of age (days post-hatch) for fish reared in laboratory aquaria at 4 different water temperatures. Parameters for a response surface regression to estimate growth as a function of water temperature and age in days post-hatch are available (Table 2).

TABLE 1. Mean total length (sample size, $s_{\bar{x}}$ ) of razorback sucker larvae at 4 constant-temperature treatments $(n=3$ tanks per treatment, 5 larvae per tank, means for individual fish) at 9, 23, and 37 days post-hatch; larvae began exogenous feeding 9 days post-hatch. For the 23-day post-hatch measurement, the 5 larvae were removed from the tanks, lightly anaesthetized, measured to the nearest $0.1 \mathrm{~mm}$ TL, and returned to the tanks. Mean mass of individual larvae at 37 days post-hatch is also shown; no mass measurements were taken at other intervals. Larvae were fed brine shrimp, Artemia sp. nauplii ad libitum twice daily.

\begin{tabular}{|c|c|c|c|c|c|c|}
\hline \multirow[b]{2}{*}{ Temperature treatment $\left({ }^{\circ} \mathrm{C}\right)$} & \multicolumn{3}{|c|}{ Mean total length (mm) } & \multirow{2}{*}{$\frac{\text { Mean mass }(\mathrm{g})}{37 \text { days }}$} & \multicolumn{2}{|c|}{$\begin{array}{l}\text { Mean growth rate } \\
\left(\mathrm{mm} \cdot \text { day }^{-1}\right)\end{array}$} \\
\hline & 9 days & 23 days & 37 days & & 9-23 days & 23-37 days \\
\hline$\overline{16.5}$ & $\begin{array}{c}11.0 \\
(8,0.27)\end{array}$ & $\begin{array}{c}15.9 \\
(14,0.28)\end{array}$ & $\begin{array}{c}21.8 \\
(13,0.59)\end{array}$ & $\begin{array}{c}0.057 \\
(13,0.005)\end{array}$ & 0.35 & 0.42 \\
\hline 19.5 & $\begin{array}{c}11.0 \\
(8,0.27)\end{array}$ & $\begin{array}{c}16.7 \\
(15,0.52)\end{array}$ & $\begin{array}{c}27.2 \\
(14,0.52)\end{array}$ & $\begin{array}{c}0.136 \\
(14,0.010)\end{array}$ & 0.40 & 0.75 \\
\hline 22.5 & $\begin{array}{c}11.0 \\
(8,0.27)\end{array}$ & $\begin{array}{c}18.4 \\
(15,0.29)\end{array}$ & $\begin{array}{c}29.2 \\
(15,0.37)\end{array}$ & $\begin{array}{c}0.175 \\
(15,0.008)\end{array}$ & 0.53 & 0.77 \\
\hline 25.5 & $\begin{array}{c}11.0 \\
(8,0.27)\end{array}$ & $\begin{array}{c}19.5 \\
(15,0.42)\end{array}$ & $\begin{array}{c}31.2 \\
(15,0.80)\end{array}$ & $\begin{array}{c}0.231 \\
(15,0.020)\end{array}$ & 0.61 & 0.84 \\
\hline
\end{tabular}

calculated days required for razorback suckers to achieve 25-mm TL under a slower growth rate $\left(0.29 \mathrm{~mm} \mathrm{TL} \cdot \mathrm{d}^{-1}\right)$ at $20^{\circ} \mathrm{C}$ (Clarkson and Childs 2000).

\section{RESULTS}

Growth of early life stages of razorback sucker was positively related to water temperature, and fastest growth occurred at $25.5^{\circ} \mathrm{C}$, the highest water temperature tested (Fig. 1, Table 1). Mean TL of razorback suckers 37 days post-hatch was $21.8 \mathrm{~mm}\left(s_{\bar{x}}=0.59\right)$ at $16.5^{\circ} \mathrm{C}$ and $31.2 \mathrm{~mm}\left(s_{\bar{x}}=0.80\right)$ at $25.5^{\circ} \mathrm{C}$. Growth was intermediate at $19.5^{\circ} \mathrm{C}$ and $22.5^{\circ} \mathrm{C}$. Growth in length $\left(\mathrm{mm} \mathrm{TL} \cdot \mathrm{d}^{-1}\right)$ of early life stages of razorback sucker was faster between 23 and 37 days post-hatch for all temperature treatments. Growth in both the early and late post-hatch periods was about twice as fast at $25.5^{\circ} \mathrm{C}\left(0.61 \mathrm{~mm} \mathrm{TL} \cdot \mathrm{d}^{-1}\right.$ and $0.84 \mathrm{~mm} \mathrm{TL} \cdot$ $\mathrm{d}^{-1}$, respectively) than growth rates in corresponding periods at $16.5^{\circ} \mathrm{C}\left(0.35 \mathrm{~mm} \mathrm{TL} \cdot \mathrm{d}^{-1}\right.$ and $0.42 \mathrm{~mm} \mathrm{TL} \cdot \mathrm{d}^{-1}$, respectively). Average weight of razorback suckers in the $25.5^{\circ} \mathrm{C}$ treatment was about 4 times that of razorback suckers in the $16.5^{\circ} \mathrm{C}$ treatment when the experiment ended. Mortalities during the experimental period were limited to 2 individuals in the $16.5^{\circ} \mathrm{C}$ treatment and 1 in the $19.5^{\circ} \mathrm{C}$ treatment; no adjustments to growth calculations were made for these fish.

Growth was mostly linear over time for the $16.5^{\circ} \mathrm{C}$ treatment and increased in a slightly exponential fashion over time in the $19.5^{\circ}, 22.5^{\circ}$, and $25.5^{\circ} \mathrm{C}$ treatments. The response surface 
TABLE 2. Parameters for a response surface model to estimate total length as a function of water temperature $(T)$, time $(D$, days post-hatch; fish were 9 days post-hatch when experiments began and 37 days post-hatch at the end), and the squared and interaction terms for those effects. The main effect for $T$ was not included $(P=0.39)$. The overall model was statistically significant $\left(F_{4,23}=\right.$ 174.2, $\left.P<0.0001, R^{2}=0.968\right)$.

\begin{tabular}{lcccc}
\hline Parameter & Estimate & $s_{\bar{x}}$ & $t$-value & $\operatorname{Pr}>t$ \\
\hline Intercept & 13.055 & 2.768 & 4.72 & $<0.0001$ \\
$D$ & -0.591 & 0.207 & 2.85 & 0.009 \\
$T \cdot T$ & -0.010 & 0.005 & 2.02 & 0.055 \\
$D \cdot D$ & 0.008 & 0.003 & 2.99 & 0.007 \\
$D \cdot T$ & 0.038 & 0.007 & 5.16 & $<0.0001$ \\
\hline
\end{tabular}

regression relationship suggested that time (days post-hatch), the squared terms for time and temperature, and the time $\times$ temperature interaction all importantly affected growth of razorback sucker larvae; the interaction was the most significant effect (Table 2).

Based on mean growth rates for each treatment, time required for razorback suckers to exceed $25 \mathrm{~mm}$ TL was 30 days (post-hatch) at $25.5^{\circ} \mathrm{C}, 33$ days at $22.5^{\circ} \mathrm{C}, 36$ days at $19.5^{\circ} \mathrm{C}$, and 41 days at $16.5^{\circ} \mathrm{C}$. Time required for slowgrowth razorback suckers to exceed $25 \mathrm{~mm}$ TL under the simulated $20^{\circ} \mathrm{C}$ temperature $(0.29$ $\mathrm{mm} \cdot \mathrm{d}^{-1}$ ) was 52 days.

\section{Discussion}

Water temperature had a strong, positive effect on growth of early life stages of razorback sucker, particularly when temperatures were $19.5^{\circ} \mathrm{C}$ or higher. A threshold was apparent, because change in mean length of razorback suckers reared at $19.5^{\circ} \mathrm{C}$ was $50 \%$ greater than for those reared at $16.5^{\circ} \mathrm{C}$ over the duration of the experiment; growth rates at higher temperatures increased at a lower rate. Differences in mean weight were even greater. Razorback suckers reared at $19.5^{\circ} \mathrm{C}$ were more than twice as heavy as those reared at $16.5^{\circ} \mathrm{C}$. I did not test colder temperatures because my main interest was determining more optimal growth conditions and because some information describing growth of early life stages of razorback sucker at cooler temperatures was already known (Clarkson and Childs 2000). These findings support those of Clarkson and Childs (2000) and others who found faster development and higher growth rates of early life stages of razorback sucker and other native fishes of the Colorado River Basin at higher water temperatures (Marsh 1985, Bestgen and Williams 1994, Bestgen 1996). Growth rates of razorback suckers at the highest water temperatures tested are relevant because water temperatures of the Green River floodplain exceeded $20^{\circ} \mathrm{C}$ in early June and reached or exceeded $25^{\circ} \mathrm{C}$ by late June (Modde et al. 2001, Christopherson et al. 2004, Modde and Haines 2005), a period just after razorback suckers hatch in the Green River (Modde et al. 2001, Bestgen et al. 2002).

Growth rates of razorback sucker larvae observed in this study were generally faster than those in most other studies, perhaps due to unlimited food rations or warmer temperatures. Laboratory-reared razorback suckers grew about $0.25 \mathrm{~mm} \cdot \mathrm{d}^{-1}$ (Bundy and Bestgen 2001), pond-reared ones grew about $0.21-0.27$ $\mathrm{mm} \cdot \mathrm{d}^{-1}$ (Papoulias and Minckley 1992), and wild fish from the Green River grew about $0.27-0.35 \mathrm{~mm} \cdot \mathrm{d}^{-1}$ (Muth et al. 2000). The faster growth rate of razorback suckers reared at $19.5^{\circ} \mathrm{C}$ in this study $\left(0.58 \mathrm{~mm} \mathrm{TL} \cdot \mathrm{d}^{-1}\right)$ compared to those reared at $20^{\circ} \mathrm{C}(0.29 \mathrm{~mm}$ $\mathrm{TL} \cdot \mathrm{d}^{-1}$ ) in Clarkson and Childs (2000) is inexplicable because both studies used the same Artemia diet, food was provided ad libitum, and razorback sucker densities in tanks were similar (2.5 fish $\cdot \mathrm{L}^{-1}$ in this study, 1.32.6 fish $\cdot \mathrm{L}^{-1}$ in Clarkson and Childs 2000). High growth rates of the few juvenile razorback suckers documented in the wild in the Green River Basin suggested that fast growth and survival may be linked (Gutermuth et al. 1994, Modde 1996, Modde et al. 2001).

Differences in time for razorback sucker larvae to achieve the hypothetical predation threshold of $25 \mathrm{~mm}$ TL under different growth rates suggested that water temperature and food resources may play a role in determining intensity of size-dependent mortality processes and survival rates in the wild. I do not imply that survival is assured once razorback suckers reach $25 \mathrm{~mm}$ TL but suggest that fast growth may be important when the early life stages of this species are in the presence of large macroinvertebrates or abundant small-bodied predaceous fishes known to prey upon cypriniform fish larvae in nursery habitats (Minckley 1973, Ruppert et al. 1993, Horn et al. 1994, Bestgen et al. 2006, Markle and Dunsmoor 2007). Increased availability of nursery areas for razorback sucker larvae that promote fast growth and are relatively free of predators 
should improve recovery prospects for this endangered species (Muth et al 2000, Modde et al. 2001).

\section{ACKNOWLEDGMENTS}

Project administration was provided by $\mathrm{R}$. Muth, J. Nusbaum, and C. Morales of Colorado State University. Razorback sucker larvae were provided by F. Pfeifer and M. Baker of the U.S. Fish and Wildlife Service, Grand Junction, Colorado. Laboratory assistance was provided by J. Bundy. This is Larval Fish Laboratory Contribution 142.

\section{Literature Cited}

Bestgen, K.R. 1990. Status review of the razorback sucker, Xyrauchen texanus. Final Report to U.S. Bureau of Reclamation, Salt Lake City, Utah. Contribution 44, Larval Fish Laboratory, Colorado State University, Fort Collins. 92 pp.

1996. Growth, survival, and starvation resistance of Colorado squawfish larvae. Environmental Biology of Fishes 46:197-209.

Bestgen, K.R., D.W. Beyers, G.B. Haines, and J.A. Rice. 1997. Recruitment models for Colorado squawfish: tools for evaluating relative importance of natural and managed processes. Final Report to U.S. National Park Service Cooperative Parks Study Unit and U.S. Geological Survey Midcontinent Ecological Science Center, Fort Collins, Colorado. Contribution 95, Larval Fish Laboratory, Colorado State University, Fort Collins. 55 pp.

Bestgen, K.R., D.W. Beyers, J.A. Rice, and G.B. Haines. 2006. Factors affecting recruitment of young Colorado pikeminnow: synthesis of predation experiments, field studies, and individual-based modeling. Transactions of the American Fisheries Society 135: $1722-1742$.

Bestgen, K.R., G.B. Haines, R. Brunson, T. Chart, M. Trammell, G. Birchell, and K. Christopherson. 2002. Decline of the razorback sucker in the Green River Basin, Utah and Colorado. Report submitted to the Recovery Implementation Program for Endangered Fishes in the Upper Colorado River Basin. Contribution 126, Larval Fish Laboratory, Colorado State University, Fort Collins. 73 pp.

Bestgen, K.R., AND M.A. WiLliams. 1994. Effects of fluctuating and constant temperatures on early development and survival of Colorado squawfish. Transactions of the American Fisheries Society 123:574579.

Bulkley, R.V., and R. Pimentel. 1983. Temperature preference and avoidance by adult razorback suckers. Transactions of the American Fisheries Society 112:601-607.

Bundy, J.M., AND K.R. Bestgen. 2001. Confirmation of daily increment deposition in otoliths of young razorback suckers. Southwestern Naturalist 46:34-40.

Carlson, C.A., And R.T. Muth. 1989. The Colorado River: lifeline of the American Southwest. Canadian Spe- cial Publication of Fisheries and Aquatic Sciences 106:220-239.

Christopherson, K.D., G.J. Birchell, and T. Modde. 2004. Larval razorback sucker and bonytail survival and growth in the presence of nonnative fish in the Stirrup floodplain. Final report to the Upper Colorado River Endangered Fish Recovery Program, Denver, Colorado. Utah Division of Wildlife Resources, Publication 05-04, Salt Lake City, UT. 24 pp.

Clarkson, R.W., and M.R. Childs. 2000. Temperature effects of hypolimnial-release dams on early life stages of Colorado River Basin big-river fishes. Copeia 2000: 402-412.

Gutermuth, F.B., L.D. Lentsch, and K.R. Bestgen. 1994. Collection of age-0 razorback suckers (Xyrauchen texanus) in the lower Green River, Utah. Southwestern Naturalist 39:389-391.

Horn, M.J., P.C. Marsh, G. Mueller, and T. Burke. 1994. Predation by odonate nymphs on larval razorback suckers (Xyrauchen texamus) under laboratory conditions. Southwestern Naturalist 39:371-374.

Mabey, L.W. 1993. Planktonic and benthic microcrustaceans from floodplain and river habitats of the Ouray Refuge on the Green River, Utah. Master's thesis, Brigham Young University, Provo, UT.

Markle, D.F., and L.K. Dunsmoor. 2007. Effects of habitat volume and fathead minnow introduction on larval survival of two endangered sucker species in Upper Klamath Lake, Oregon. Transactions of the American Fisheries Society 136:567-579.

Marsh, P.C. 1985. Effect of incubation temperature on survival of embryos of native Colorado River fishes. Southwestern Naturalist 30:129-140.

Marsh, P.C., and D.R. Langhorst. 1988. Feeding and fate of wild larval razorback sucker. Environmental Biology of Fishes 21:59-67.

MinckLey, W.L. 1973. Fishes of Arizona. Arizona Game and Fish Department, Phoenix. 293 pp.

Minckley, W.L., P.C. Marsh, J.E. Brooks, J.E. Johnson, AND B.L. Jensen. 1991. Management toward recovery of the razorback sucker. Pages 303-357 in W.L. Minckley and J.E. Deacon, editors, Battle against extinction: native fish management in the American West. University of Arizona Press, Tucson. $517 \mathrm{pp}$.

ModDE, T. 1996. Juvenile razorback sucker (Xyrauchen texanus) in a managed wetland adjacent to the Green River. Great Basin Naturalist 56:375-376.

Modde, T., K.P. Burnham, And E.J. Wick. 1996. Population status of the razorback sucker in the middle Green River. Conservation Biology 10:110-119.

Modde, T., And G.B. Haines. 2005. Survival and growth of stocked razorback sucker and bonytail in multiple floodplain wetlands of the middle Green River under reset conditions. Final Report to the Upper Colorado River Basin Recovery Implementation Program, U.S. Fish and Wildlife Service, Denver, Colorado. U.S. Fish and Wildlife Service, Vernal, UT. $66 \mathrm{pp}$.

Modde, T., R.T. Muth, and G.B. Haines. 2001. Floodplain wetland suitability, access, and potential use by juvenile razorback suckers in the Middle Green River, Utah. Transactions of the American Fisheries Society 130:1095-1105.

Muth, R.T., L.W. Crist, K.E. LaGory, J.W. Hayse, K.R. Bestgen, T.P. Ryan, J.K. Lyons, and R.A. Valdez. 
2000. Flow and temperature recommendations for endangered fishes in the Green River downstream of Flaming Gorge Dam. Final Report FG-53 to the Upper Colorado River Endangered Fish Recovery Program. U.S. Fish and Wildlife Service, Denver, CO.

Olden, J.D., N.L. Poff, and K.R. Bestgen. 2006. Lifehistory strategies predict fish invasions and extirpations in the Colorado River Basin. Ecological Monographs 76:25-40.

Papoulias, D., and W.L. Minckley. 1990. Food limited survival of larval razorback sucker, Xyrauchen texanus, in the laboratory. Environmental Biology of Fishes 29:73-78.

1992. Effects of food availability on survival and growth of larval razorback suckers in ponds. Transactions of the American Fisheries Society 121:340-355.

Poff, N.L., J.D. Allan, M.B. Bain, J.R. KarR, K.L. PresteGaARD, B.D. Richter, R.E. Sparks, and J.C. STROMBERG. 1997. The natural flow regime. BioScience 47:769-784.

Rice, J.A., T.J. Miller, K.A. Rose, L.B. Crowder, E.A. Marschall, A.S. Trebitz, and D.L. DeAngelis. 1993. Growth rate variation and larval survival: inferences from an individual-based size-dependent predation model. Canadian Journal of Fisheries and Aquatic Sciences 50:133-142.
Ruppert, J.B., R.T. Muth, And T.P. Nesler. 1993. Predation on fish larvae by adult red shiner, Yampa and Green rivers, Colorado. Southwestern Naturalist 38: 397-399.

Stanford, J.A., J.V. Ward, W.J. Liss, C.A. Frizzell, R.N. Williams, J.A. Lichatowich, and C.C. Coutant. 1996. A general protocol for restoration of regulated rivers. Regulated Rivers: Research and Management 12:391-413.

Tyus, H.M., AND C.A. KarP. 1989. Habitat use and streamflow needs of rare and endangered fishes, Yampa River, Colorado. U.S. Fish and Wildlife Service Biological Report 89(14):1-27.

1990. Spawning and movements of razorback sucker, Xyrauchen texanus, in the Green River basin of Colorado and Utah. Southwestern Naturalist 35:427-433.

VALDEZ, R.A., AND R.T. MUTH. 2005. Ecology and conservation of native fishes in the Upper Colorado River Basin. American Fisheries Society Symposium 45: 157-204.

Weatherly, A.H., and H.S. Gill. 1987. The biology of fish growth. Academic Press, San Diego, CA.

Received 31 October 2006 Accepted 23 July 2007 